\title{
Stratification of the microbial community inhabiting an anchialine sinkhole
}

\author{
J. R. Seymour ${ }^{1,3, *}$, W. F. Humphreys ${ }^{2}$, J. G. Mitchell ${ }^{1}$ \\ ${ }^{1}$ Flinders University of South Australia, School of Biological Sciences, PO Box 2100, Adelaide, South Australia 5001, \\ Australia \\ ${ }^{2}$ Western Australian Museum, Locked Bag 49, Welshpool DC, Western Australia 6986, Australia \\ ${ }^{3}$ Present address: Massachusetts Institute of Technology, Department of Civil \& Environmental Engineering, \\ 77 Massachusetts Ave., Cambridge, Massachusetts 02139, USA
}

\begin{abstract}
Bundera Sinkhole in northwestern Australia is an anchialine ecosystem characterised by a highly stratified water column comprising a complex polymodal profile of several physico-chemical parameters. We studied the microscale and finescale dynamics of the resident microbial community within the sinkhole. Sub-millimetre scale distributions of phytoplankton abundance were measured in the top $8 \mathrm{~m}$ of the water column using a free-falling high resolution fluorometer. Depth profiles were characterised by a strong, 10 to $20 \mathrm{~cm}$ layer of elevated fluorescence, occurring at approximately $1 \mathrm{~m}$ depth, which despite changes in magnitude and width was found to persist during a $24 \mathrm{~h}$ sampling period. Near surface distributions of microbial populations were measured using a syringe sampling profiler, which allowed for collection of water samples at $5 \mathrm{~cm}$ resolution, and flow cytometric analysis. These samples revealed a complex microbial assemblage, with multiple subpopulations of viruses, bacteria and picophytoplankton present throughout the water column. Within $3 \mathrm{~m}$ profiles, the bacterial and virus populations showed marked shifts in relative abundance, with changes of over 35-fold observed across as little as $20 \mathrm{~cm}$. Samples collected from the surface to a depth of $30 \mathrm{~m}$ by divers also revealed distinct peaks and layers in the relative abundance of the different bacteria and virus sub-populations, which often corresponded to heterogeneities in chemical and nutrient parameters, and at some depths indicated the prevalence of chemolithotrophic populations. The complex patterns described here represent the first comprehensive observations of microbial spatiotemporal dynamics throughout an anchialine ecosystem and reveal a highly structured microbial habitat consisting of discrete niches, each dominated by heterotrophic, phototrophic or chemoautotrophic microorganisms.
\end{abstract}

KEY WORDS: Anchialine · Sinkhole • Bacteria • Stratification • Chemoautotrophy • Virus • Phytoplankton

Resale or republication not permitted without written consent of the publisher

\section{INTRODUCTION}

Anchialine ecosystems are inland, often underground, aquatic habitats comprising a mixohaline water column, where a freshwater surface overlays a body of intruding coastal seawater, which is linked to the ocean by a subterranean, usually karstic connection (Stock et al. 1986). These unique ecosystems are generally characterised by a high species richness and diversity of micro- and macroorganisms, many of which are restricted to anchialine habitats (Yager \& Humphreys 1996, Iliffe 2000, Bishop et al. 2004).
Anchialine systems are typically characterised by 'meromictic', or permanently stratified, water columns with complex physico-chemical profiles, incorporating strong and coherent halo- and thermoclines, as well as prominent hypoxic and anoxic regions and concentrated layers of hydrogen sulphide $\left(\mathrm{H}_{2} \mathrm{~S}_{\text {; }}\right.$ Stock et al. 1986, Bishop et al. 2004). Consequently, anchialine habitats generally support diverse and often chemolithotrophic microbial assemblages (Pohlman et al. 1997, Donachie et al. 1999). However, very few studies have investigated the ecology and spatiotemporal dynamics of microbial communities with- 
in anchialine ecosystems (Alcocer et al. 1999). An understanding of microbial community dynamics within these ecosystems is of importance because microbe-mediated processes contribute to the establishment of oxic and nutrient gradients (Fenchel \& Finlay 1995), which influence the ecology of a number of unique species of fish and crustaceans that inhabit anchialine habitats (Humphreys 2001). Furthermore, subterranean habitats such as these provide an opportunity to study the trophic dynamics of systems where photosynthetic activity is minimal or absent, and microbial chemoautotrophy can be the dominant form of primary production (Sarbu et al. 1996, Pohlman et al. 1997).

Within other limnetic systems, where persistent physico-chemical gradients occur, the spatiotemporal distributions of microbial populations are often highly stratified. A dense body of literature has examined the spatial distributions of zooplankton, phytoplankton, bacteria and viruses within lake systems and has demonstrated the re-occurrence of stratification of planktonic abundance, community composition and activity, which occurs in concomitance with a variety of biophysical parameters (e.g. Gasol et al. 1991, Weinbauer \& Hofle 1998, Goddard et al. 2005). Anchialine systems, however, often incorporate unique physicochemical characteristics, including polymodal oxygen profiles (Humphreys 1999) possibly generated by the subterranean tidal influx of marine waters, and the manner that microbial populations are distributed and interact within these complex physical settings is virtually unknown.

Bundera Sinkhole is the only deep anchialine ecosystem known in Australia, and several new species of copepods, remipeds and polychaetes have been identified at the site (Yager \& Humphreys 1996, Danielopol et al. 2000, Jaume \& Humphreys 2001, Wilson \& Humphreys 2001). The sinkhole exhibits a strong polymodal vertical stratification in the physico-chemical profile, and there is putative evidence for significant levels of microbial chemosynthesis (Humphreys 1999). However, to date there has not been a comprehensive survey of the microbial dynamics within this system, and universally there is paucity of knowledge regarding anchialine microbial ecology. Here, we present the first investigation of the spatial dynamics of multiple microbial populations, including discrete groups of phytoplankton, bacteria and viruses, within an anchialine sinkhole. In doing so, we reveal to what extent the unique and highly stratified physico-chemical environment of anchialine systems creates small- and micro-scale spatial structure and variability in the distributions and composition of planktonic microbial communities.

\section{MATERIALS AND METHODS}

Site description. Sampling was conducted at Bundera Sinkhole (Australian Karst Index C-28), located $1.7 \mathrm{~km}$ inland from the Indian Ocean in northwestern Australia $\left(22^{\circ} 23^{\prime} \mathrm{S}, 113^{\circ} 47^{\prime} \mathrm{E}\right)$, between 5 and 9 June 2005. The water surface in the sinkhole lies approximately $5 \mathrm{~m}$ below a flat $4.5 \mathrm{~km}$ wide coastal plain, which provides shelter from the prevailing winds, inhibiting vertical mixing and contributing to the meromictic nature of the water column. The upper 7 to $10 \mathrm{~m}$ of the sinkhole are composed of a $10 \mathrm{~m}$ wide basin that funnels into a narrow (1 to $5 \mathrm{~m}$ ) cave, extending $70 \mathrm{~m}$ from its mouth to a depth of $33 \mathrm{~m}$ underground (see Fig. 1 in Humphreys 1999). The water column in Bundera Sinkhole is characterised by a strong thermo-halocline at ca. $7.5 \mathrm{~m}$ and is subject to the marine tidal cycle, the amplitude of which is dampened to ca. $10 \%$ of that at the coast (W. F. Humphreys unpubl.).

Physical measurements. Physical parameters, including temperature, salinity and dissolved $\mathrm{O}_{2}$, were measured independently using 2 profiling devices. Profiles in the upper water column were obtained by lowering a Quanta-G tethered data sonde (Hydrolab, Austin, TX, USA) manually through the top $8 \mathrm{~m}$ of the water column, while profiles throughout the remainder of the water column were obtained using a Troll 9000 data sonde (In-Situ ${ }^{\circledR}$, Fort Collins, CO, USA), which was deployed by SCUBA divers using re-breathing apparatus. Water samples for chemical analysis were also collected by divers in sterile $50 \mathrm{ml}$ centrifuge tubes. $\mathrm{H}_{2} \mathrm{~S}$ concentrations were measured on site using a Chemetrics test kit (CHEMets sulphide R-9510). Samples for dissolved inorganic nitrogen (DIN) species $\left(\mathrm{NO}_{2}^{-}, \mathrm{NO}_{3}^{-}, \mathrm{NH}_{4}^{+}\right)$were frozen in the field and analysed within $7 \mathrm{~d}$ using standard methods at the Chemistry Centre analytical laboratories, Perth, Western Australia.

Fluoromap profiles. Microscale profiles of chlorophyll (chl) a were obtained in the top $8 \mathrm{~m}$ of the water column using a high-resolution fluorometer (FluoroMAP; Fluorescence Microscale Acquisition Profiler, Alec Electronic, Kobe, Japan). This instrument, which is described in detail elsewhere (Doubell et al. 2006), incorporates a blue diode laser (NLPB320, Nichia Chemical), which excites chlorophyll at $450 \mathrm{~nm}$, and detectors for measuring both fluorescence (640 to $720 \mathrm{~nm}$ ) and depth (up to $70 \mathrm{~m}$ ). FluoroMAP accumulates data at $512 \mathrm{~Hz}$ allowing for the acquisition of fluorescence depth profiles at sub-centimetre spatial resolution. During this study, high resolution chl a profiles were obtained by slowly lowering FluoroMAP through the water column, with the aid of a pulley system. Profiles were taken every $3 \mathrm{~h}$ during a $24 \mathrm{~h}$ light cycle. 
Microprofiles and diver-retrieved samples. A pneumatically operated, syringe-based sampling device, consisting of a linear array of $50 \mathrm{ml}$ syringes, each separated by a distance of $5 \mathrm{~cm}$ and connected along a hollow copper pipe, was employed to obtain a microscale vertical profile of picophytoplankton, bacteria and virus abundance in the top $3 \mathrm{~m}$ of the water column. This device allowed for the unobtrusive, high resolution collection of samples in the upper waters of the sinkhole. Samples throughout the remainder of the sinkhole, from the surface to the bottom $(30 \mathrm{~m})$, were collected in sterile $50 \mathrm{ml}$ tubes at $1 \mathrm{~m}$ resolution by research divers. This permitted the collection of samples from regions of the sinkhole not accessible by standard sampling equipment. To limit the disruption of any vertical stratification, the divers employed rebreathing apparatus, which minimises the effects of diving on the finescale biophysical spatial structure within sinkholes (Humphreys et al. 1999). All samples were fixed with $1 \%$ (final concentration) paraformaldehyde and quick frozen in liquid nitrogen.

Flow cytometry. All flow cytometric (FCM) analysis was conducted using a Becton Dickinson FACScanto flow cytometer, equipped with air-cooled $20 \mathrm{~mW}$ solid state $488 \mathrm{~nm}$ and $17 \mathrm{~mW}$ HeNe $633 \mathrm{~nm}$ lasers, and with phosphate-buffered saline (PBS) solution employed as a sheath fluid. Prior to analysis, frozen samples were quick thawed and divided into separate aliquots for enumeration of phytoplankton, bacteria and viruses. Samples for phytoplankton enumeration were analysed unstained, while those for bacteria and virus enumeration were diluted 10 - or 50 -fold in $0.02 \mu \mathrm{m}$ filtered TE buffer (10 mM Tris, 1 mM EDTA [pH 7.5]), before being stained with SYBR-I Green solution (5:100 000 dilution; Molecular Probes), and incubated in the dark for $15 \mathrm{~min}$ (Marie et al. 1999). These samples were also heated to $80^{\circ} \mathrm{C}$ for 10 min during SYBR Green incubation, as heating optimises FCM viral counts (Brussaard 2004). Fluorescent beads of $1 \mu \mathrm{m}$ diameter (Molecular Probes) were added to all samples in a final concentration of approximately $10^{5}$ beads $\mathrm{ml}^{-1}$ (Gasol \& del Giorgio 2000), and all measured cytometry parameters were normalised to bead concentration and fluorescence.

For each sample, Forward Scatter (FSC), Side Scatter (SSC), green (SYBR-I) fluorescence, red fluorescence and orange fluorescence were acquired. For phytoplankton analysis, sample acquisition was run until at least 100 to $200 \mu \mathrm{l}$ of unstained sample were analysed at a rate of approximately $40 \mu \mathrm{min}^{-1}$. Sub-populations of picophytoplankton were discriminated according to differences in red (chlorophyll) fluorescence and SSC (Marie et al. 1999). For enumeration of bacteria and viruses, sample acquisition was run until at least 50 to $100 \mu \mathrm{l}$ of sample were analysed at an event rate of
$<800 \mathrm{~s}^{-1}$. Individual virus and bacterial sub-populations were separated according to variations in SYBR Green fluorescence and light SSC (Marie et al. 1997, 1999). Data for individual sub-samples was collected in listmode files, and populations were identified and enumerated using Win Midi 2.8 (@Joseph Trotter, Scripps Institute, La Jolla, CA, USA) FCM analysis software.

\section{RESULTS}

\section{Physico-chemical conditions}

During the time of sampling, Bundera Sinkhole was characterised by a strong $\mathrm{H}_{2} \mathrm{~S}$ odour, and the surface layer of the sinkhole was partially covered by white veils of sulphur-oxidising bacteria (Fenchel 1994). In comparison to previous observations made at Bundera Sinkhole (Humphreys 1999, W. F. Humphreys unpubl.), the upper layer of the water column was relatively turbid, with light levels dropping to very low levels below $2 \mathrm{~m}$ depth (diver observations). Water temperatures throughout the water column varied by less than $2^{\circ} \mathrm{C}$, with a gradual increase in temperature to $26.2^{\circ} \mathrm{C}$ at a depth of approximately $7.5 \mathrm{~m}$, below which temperatures remained relatively uniform (Fig. 1A). Salinity levels increased from 15.7 PSU at the surface to $28 \mathrm{PSU}$ at approximately 7.5 to $8 \mathrm{~m}$ depth, where the halocline occurred, below which salinity levels stabilised, reaching a maximum of 34.8 PSU (Fig. 1B).

Dissolved oxygen concentrations exhibited a complex vertical profile, presumably influenced by the subterranean intrusion of marine waters. Near surface $\mathrm{O}_{2}$ concentrations were measured by lowering a Quanta-G data sonde to prevent potential surface exchange as divers entered and departed the water. In the upper few metres of the water column, oxygen levels dropped sharply from $4.9 \mathrm{mg} \mathrm{l}^{-1}$ at the surface to $0.2 \mathrm{mg} \mathrm{l}^{-1}$ at $2.5 \mathrm{~m}$ depth (Fig. $1 \mathrm{C}_{\text {; }}$ inset). Beyond this depth, oxygen levels remained relatively low (<ca. $0.3 \mathrm{mg} \mathrm{l}^{-1}$ ), with the exception of a marked secondary peak occurring at depth of approximately $9 \mathrm{~m}$ and coinciding with the upper metre of the marine segment of the water column, where $\mathrm{O}_{2}$ concentrations increased to $1.6 \mathrm{mg} \mathrm{l}^{-1}$ (Fig 1C). Two further, although weaker, peaks in $\mathrm{O}_{2}$ concentration also occurred between $16-21 \mathrm{~m}$ and $25-30 \mathrm{~m}$.

$\mathrm{H}_{2} \mathrm{~S}$ concentrations reached a maximum of $520 \mu \mathrm{M}$ at a depth of $3 \mathrm{~m}$, before decreasing to undetectable levels below $8 \mathrm{~m}$ and remaining very low throughout the remainder of the water column (Fig. 2A). The position of this single $\mathrm{H}_{2} \mathrm{~S}$ layer was apparently bound by the oxic layers occurring both immediately above and below it. Profiles of DIN were also characterised by marked concentration peaks, with $\mathrm{NH}_{4}$ exhibiting a 


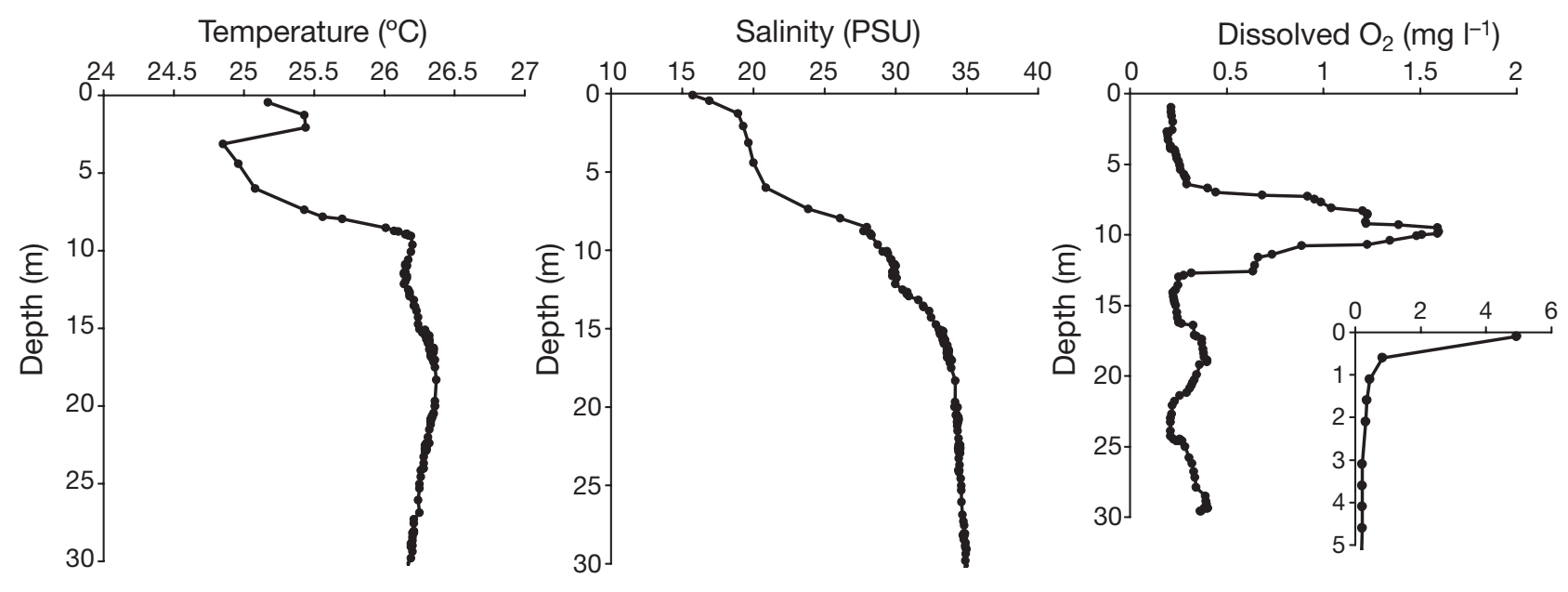

Fig. 1. Physical conditions throughout Bundera Sinkhole. (A) Temperature, (B) salinity and (C) dissolved oxygen measurements were obtained with a Troll 9000 data sonde, deployed by divers using re-breathing apparatus. (C, inset) dissolved oxygen concentrations obtained for upper $5 \mathrm{~m}$ using a Quanta-G data sonde lowered manually to reduce effects of divers disturbing

the atmosphere-water column interface
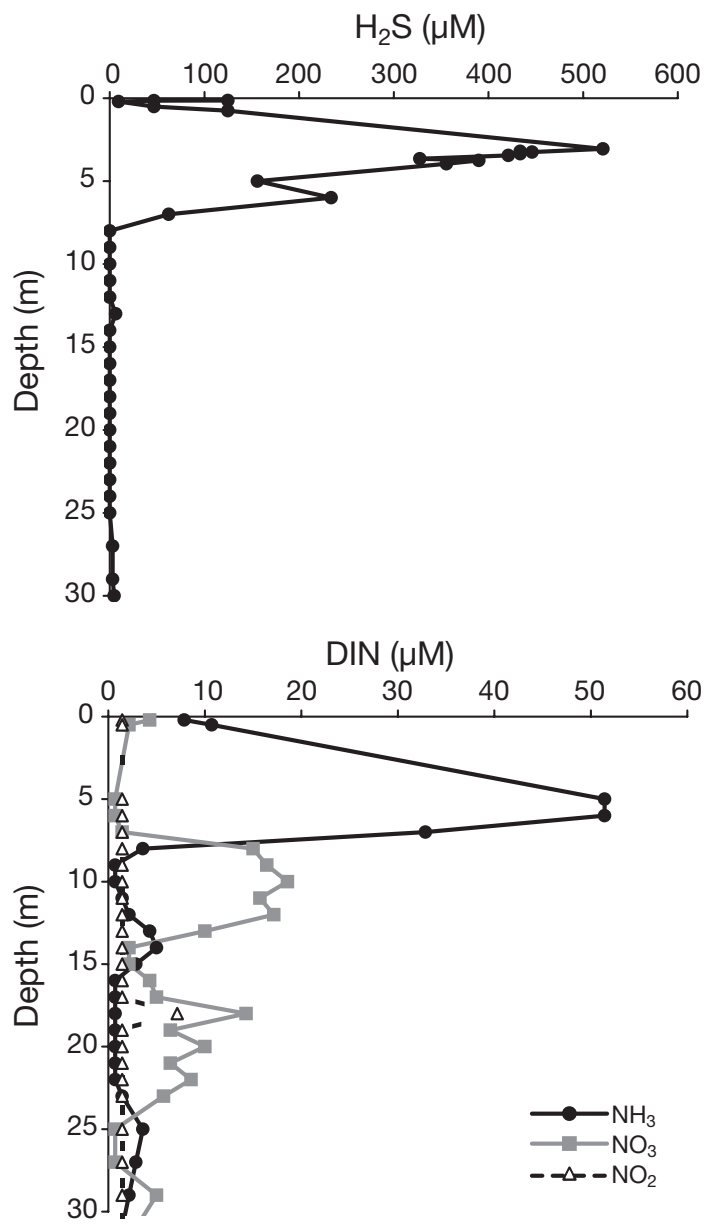

Fig. 2. Concentrations of hydrogen sulphide $\left(\mathrm{H}_{2} \mathrm{~S}\right)$ and dissolved inorganic nitrogen (DIN) throughout Bundera Sinkhole similar spatial pattern to $\mathrm{H}_{2} \mathrm{~S}$, with a broad concentration peak between 1 and $7 \mathrm{~m}$, where maximum concentrations reached $51.5 \mu \mathrm{M}$ (Fig. 2B). $\mathrm{NO}_{3}$ exhibited an inverse distribution to $\mathrm{NH}_{4}$, with broad concentration peaks of 14 to $18 \mu \mathrm{M}$ between $8-12 \mathrm{~m}$ and 17-22 $\mathrm{m}$ corresponding to minima in $\mathrm{NH}_{4}$ (Fig. 2B). $\mathrm{NO}_{2}$ exhibited low and uniform concentrations throughout the profile, with a slight peak of $7.1 \mu \mathrm{M}$ at $18 \mathrm{~m}$ (Fig. 2B).

\section{In situ fluorescence profiles}

Using FluoroMAP, a high resolution fluorometer, we were able to measure the microscale spatial distribution of phytoplankton within the Bundera Sinkhole at a spatial resolution of approximately $0.5 \mathrm{~mm}$. Measurements were limited to the upper $7 \mathrm{~m}$ of the water column, because the coarse and narrow topology of the sinkhole beyond this depth prevented the fluorometer from being safely lowered to greater depths. During the $24 \mathrm{~h}$ sampling period, fluorescence depth profiles exhibited several consistent features (Fig. 3). Profiles were generally characterised by low levels of fluorescence from the surface to a depth of approximately $1 \mathrm{~m}$, before the occurrence of a persistent thin (10 to $20 \mathrm{~cm}$ ) layer of high fluorescence, which, while changing in magnitude, remained the dominant feature of vertical profiles during the $24 \mathrm{~h}$ sampling period. Beneath this layer, a shoulder of uniform fluorescence occurred for $2 \mathrm{~m}$, before fluorescence dropped to very low levels below a depth of approximately $4 \mathrm{~m}$.

The intensity of the thin layer of high fluorescence reached a maximum at 12:00 $\mathrm{h}$, when fluorescence 


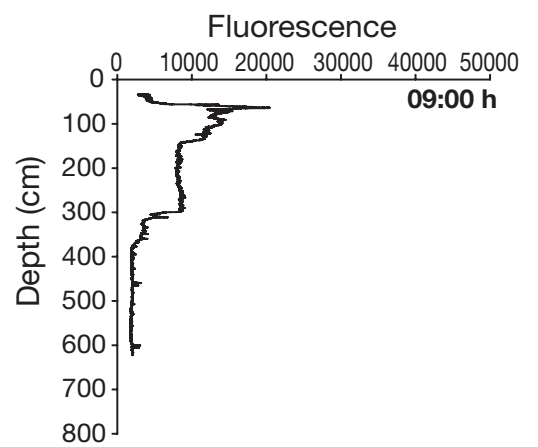

Fluorescence

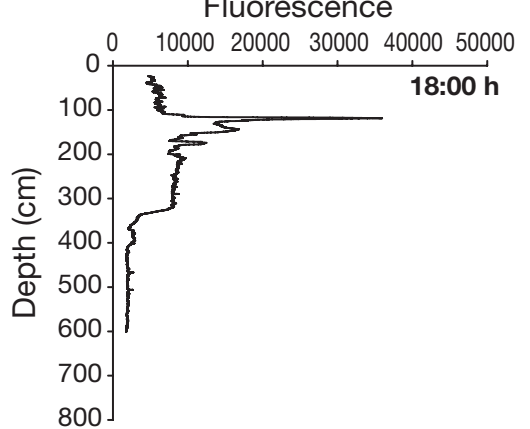

Fluorescence

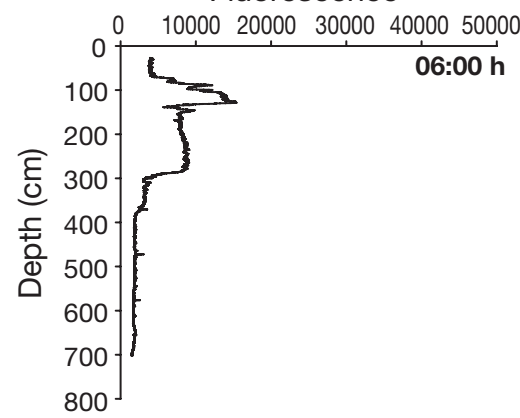

Fluorescence

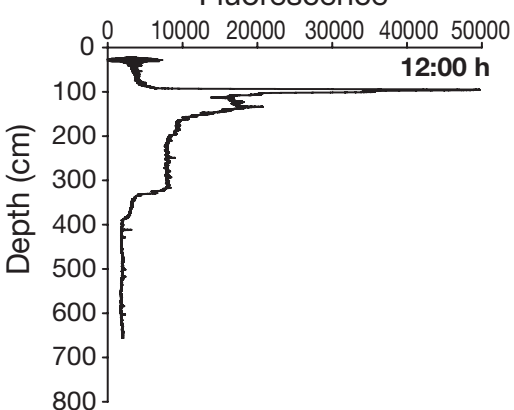

Fluorescence

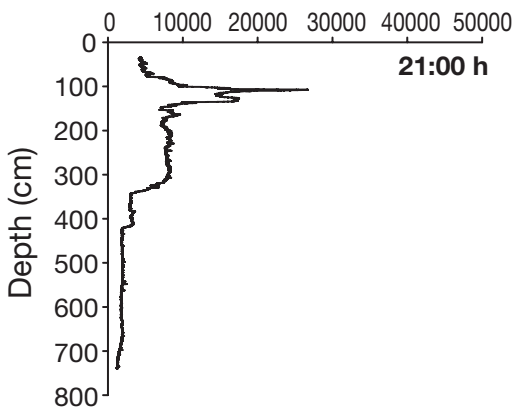

Fluorescence

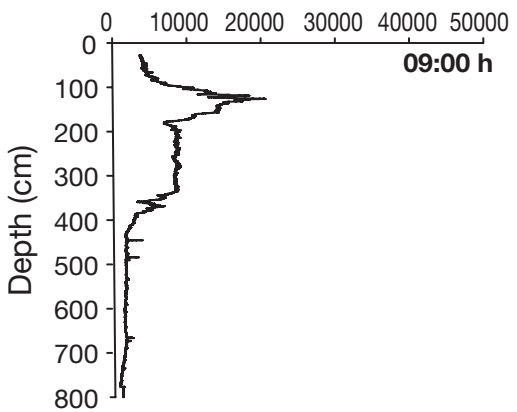

Fluorescence

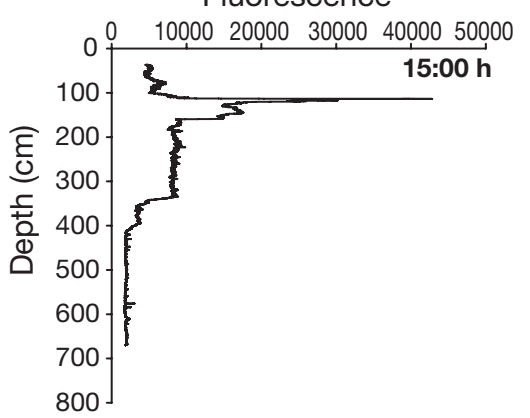

Fluorescence

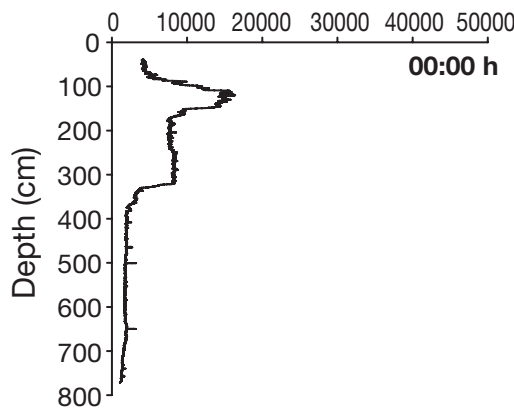

Fig. 3. Fluorescence profiles obtained with FluoroMAP in the upper $8 \mathrm{~m}$ of Bundera Sinkhole, during a $24 \mathrm{~h}$ light cycle. Measurements were obtained at $512 \mathrm{~Hz}$, corresponding to a spatial resolution of approximately $0.5 \mathrm{~mm}$

within it reached more than 10 times background levels (Fig. 3). During the course of the afternoon and evening, the fluorescence levels within this layer decreased in intensity, until 00:00 h, when fluorescence was only 3 times above background levels (Fig. 3). During the following morning fluorescence levels within this peak began to increase again to levels comparable to those observed $24 \mathrm{~h}$ prior (Fig. 3).

\section{Microbial communities identified using FCM}

Samples analysed for microbial parameters, including bacteria, virus and phytoplankton abundance, were characterised by a highly complex community structure, with multiple sub-populations of each group identified at different depths throughout the sinkhole. FCM analysis revealed 4 distinct populations of viruslike particles, at least 6 populations of bacteria and 2 groups of picophytoplankton.
Two discrete populations of unidentified picophytoplankton, designated here as PP1 and PP2, were discriminated according to red fluorescence (chlorophyll content) and light scatter properties (size) of cells (Marie et al. 1999) (data not shown). Neither population exhibited detectable orange fluorescence, characteristic of Synechococcus or Synechocystis-type cyanobacteria, and their cell size was comparable to pico-eukaryotic phytoplankton populations often identified in seawater and lake samples (Olson et al. 1989, Goddard et al. 2005).

Virus populations were discriminated according to SSC and SYBR Green fluorescence (Marie et al. 1999). All virus populations identified here were removed by filtration through $0.2 \mu \mathrm{m}$ membrane filters, indicating that all particles within these populations were smaller than bacteria. Two clusters of virus-like particles, denoted as groups V1 and V2, varied slightly in SYBR Green fluorescence, and were present in most samples (Fig. 4). Another cluster of virus-like particles (virus 

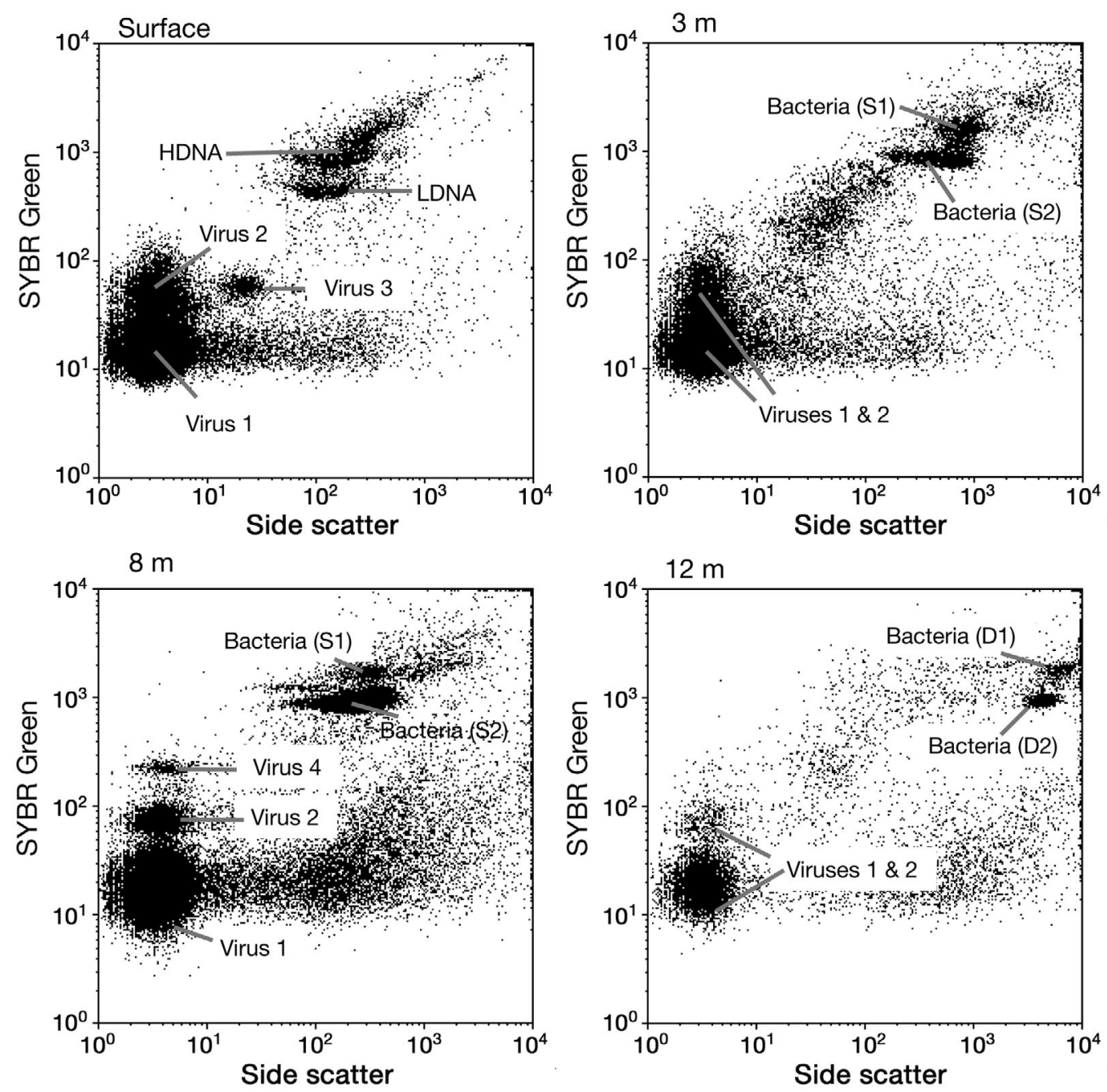

Fig. 4. Flow cytometric characterisation of bacteria and virus sub-populations. Populations were discriminated according to differences in SYBR Green fluorescence and side scatter

group V3) exhibited levels of SYBR Green fluorescence similar to $\mathrm{V} 2$, but significantly higher levels of SSC (Fig. 4). Alternatively, virus group V4 exhibited levels of SSC similar to V1 and V2, but higher levels of SYBR Green fluorescence (Fig. 4).

The 6 sub-populations of bacteria consistently identified here could be categorised into 3 distinct groups, according to differences in SSC and location of occurrence in the water column. Two sub-populations, exhibiting the cytometric characteristics typical of heterotrophic bacterial populations observed in most lake and seawater samples, occurred in samples collected in the top $5 \mathrm{~m}$ of the sinkhole (Fig. 4). These groups, denoted here as low and high DNA (LDNA and HDNA; Gasol et al. 1999), were differentiated from one another according to differences in SYBR Green fluorescence. The other 4 bacterial populations identified exhibited dissimilar FCM characteristics to any that we are aware of in the previous literature. These groups are identified here as non-phototrophic bacterial populations, because their size and nucleic acid content are consistent with bacterial-sized organisms, and because they lack red or orange fluorescence, which is indicative of cellular chlorophyll or photo-pigment content (Marie et al. 1999). Groups S1 and S2 exhibited slightly higher SSC and SYBR Green fluorescence than the LDNA and HDNA populations and typically occurred in samples collected from greater depth than the LDNA and HDNA groups (Fig. 4). Groups D1 and D2 exhibited similar SYBR Green levels to the other groups, but much higher levels of SSC, indicative of a larger cell size (Button et al. 1996), and were only observed in significant numbers below a depth of $7 \mathrm{~m}$ (Fig. 4). 


\section{Microscale vertical profile}

Vertical profiles taken in the top $3 \mathrm{~m}$ of the water column showed marked microscale variability in the abundance and composition of the microbial commu- nity. The distributions of the 2 phytoplankton groups broadly corresponded to the fluorescence profiles taken using FluoroMAP (Fig. 5A,B). While PP1 was almost an order of magnitude more abundant than PP2, the groups exhibited similar depth profiles, with a peak in abundance occurring between 70 and $140 \mathrm{~cm}$ (Fig. 5B).
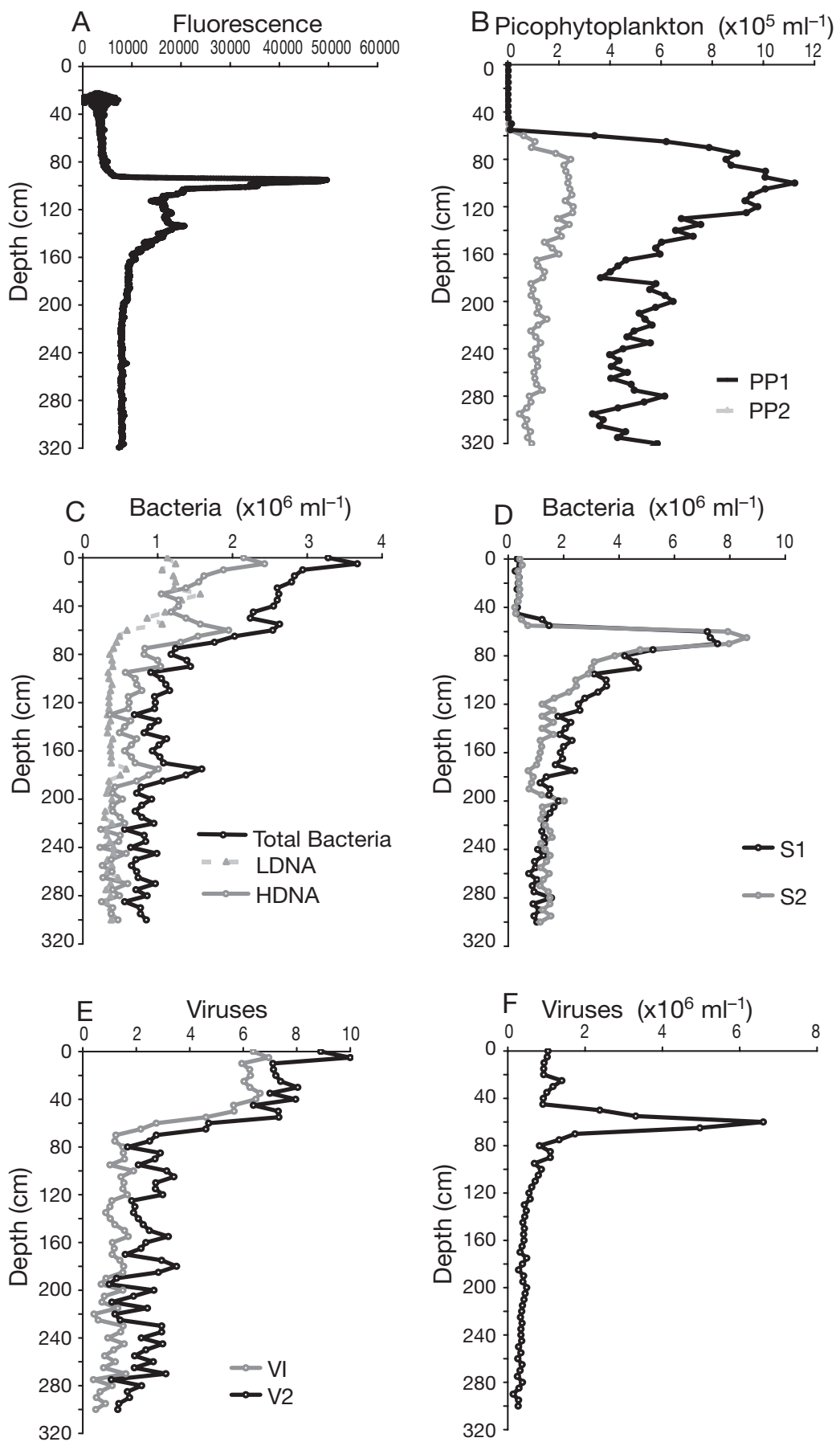

Fig. 5. Microscale distributions of phytoplankton, bacteria and viruses within the top $3 \mathrm{~m}$ of Bundera Sinkhole. In (C), Total Bacteria refers to the sum of LDNA and HDNA bacteria. Sub-samples were collected at a spatial resolution of $5 \mathrm{~cm}$ using a pneumatically operated sampling device and analysed using flow cytometry
The LDNA and HDNA bacterial groups and their sum, considered here as the total aerobic heterotrophic bacterial population (see below), exhibited a clear trend of maximum abundance near the surface and a decrease in abundance over the top metre of the water column (Fig. 5C). The mean total concentration of this population was $1.95 \times 10^{6} \mathrm{ml}^{-1}$, but decreased by 6.5 -fold over the top $3 \mathrm{~m}$ of the water column. The LDNA and HDNA sub-populations also decreased by 5.5and 10.5-fold, respectively, in the upper $3 \mathrm{~m}$ of Bundera Sinkhole.

Bacterial groups S1 and S2 occurred in mean concentrations of 1.7 and $2.0 \times$ $10^{6} \mathrm{ml}^{-1}$, respectively, and exhibited highly correlated $(\mathrm{r}=0.94, \mathrm{p}<0.05)$ spatial patterns in the top $3 \mathrm{~m}$ of the water column. Both groups exhibited a strong peak in abundance, in the form of a $30 \mathrm{~cm}$ thick layer, at a depth of approximately $60 \mathrm{~cm}$ (Fig. 5D), where the concentrations of the S1 and S2 populations increased by 36 - and 30 -fold, respectively, within the space of 20 to $30 \mathrm{~cm}$. No significant correlation was observed between any of the bacterial sub-populations and either of the picophytoplankton groups ( $p>0.05)$.

Virus groups V1 and V2 occurred in mean concentrations of $2.2 \times 10^{7} \mathrm{ml}^{-1}$ and $3.4 \times 10^{6} \mathrm{ml}^{-1}$, respectively, and showed a similar vertical profile to the HDNA and LDNA bacterial groups, with a clear decrease in abundance occurring over the top $1 \mathrm{~m}$ of the water column (Fig. 5E). The spatial distributions of both V1 and V2 were significantly correlated to each of these bacterial groups ( $\mathrm{r}>0.93, \mathrm{p}<$ 0.05). V3 exhibited an entirely different vertical profile, with a clear peak in abundance at a depth of $60 \mathrm{~cm}$, where concentrations reached up to 20 times background. The distribution of the V3 population was correlated to the S1 and S2 bacterial populations ( $\mathrm{r}>0.69, \mathrm{p}<$ 0.05). 


\section{Water column profiles}

Samples retrieved by divers at a depth resolution of $1 \mathrm{~m}$ also showed a complex vertical profile throughout the water column of Bundera Sinkhole. However, the population structure beyond $5 \mathrm{~m}$ was inherently different from that observed in the microscale profile obtained from the top $3 \mathrm{~m}$ of the water column. Neither of the picophytoplankton populations occurred in significant densities below a depth of $7 \mathrm{~m}$ (Fig. 6A), and the HDNA and LDNA bacterial populations could not be detected below a depth of $5 \mathrm{~m}$. The other bacterial populations, however, including the S1, S2, D1 and D2 groups, exhibited stratified distributions. Each of these populations, as well as all 4 of the virus populations, exhibited strong maxima at a depth of 7 to $8 \mathrm{~m}$, corresponding to the thermo-halocline (Fig. 6B,C,D). Within this region, concentrations of these populations were between 2 and 10 times higher than elsewhere in the water column.

During sample collection, divers observed the occurrence of dense white veils, or clouds, presumably of sulphur-oxidising bacteria, throughout the water col-
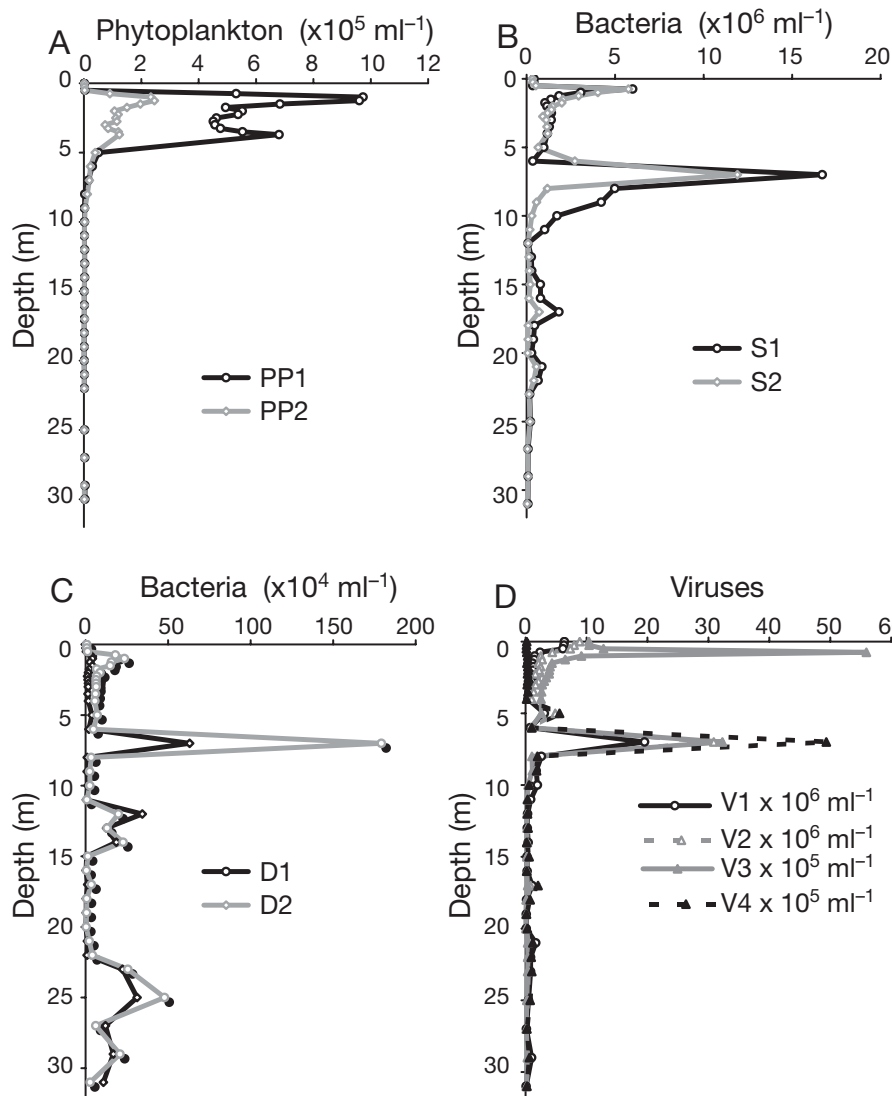

Fig. 6. Depth profiles of phytoplankton, bacteria and viruses throughout Bundera Sinkhole. Samples were collected in sterile centrifuge tubes at $1 \mathrm{~m}$ resolution by divers using rebreathing apparatus and analysed using flow cytometry umn (Fig. 7). Analysis of samples collected within this region revealed slight increases in abundance in the S1 and S2 bacterial populations at depths of 17 and $21 \mathrm{~m}$, while the D1 and D2 bacterial populations showed increases in abundance between depths of 11 and $15 \mathrm{~m}$ and 22 and $30 \mathrm{~m}$ (Fig. 6C). However, none of the virus populations were observed in significant numbers below $8 \mathrm{~m}$ (Fig. 6D)

\section{DISCUSSION}

\section{Physico-chemical structure of the water column}

In addition to exhibiting the characteristic conditions defining an anchialine system, where a lens of cooler fresh-brackish water overlays a body of warmer seawater (Stock 1986), the biochemical structure within the water column of Bundera Sinkhole is highly complex, with coherent layers and steep gradients of oxygen, $\mathrm{H}_{2} \mathrm{~S}$ and DIN apparent. The subterranean intrusion of seawater within anchialine systems can generate physico-chemical profiles that are dissimilar to the patterns typically observed in more stable limnetic settings. Within Bundera Sinkhole, the most apparent realisation of this effect was the polymodal dissolved $\mathrm{O}_{2}$ profile. The presence of oxic layers beneath the chemocline is generally not expected in typical lake environments, but there is consistent evidence of oxygenated water occurring beneath $\mathrm{H}_{2} \mathrm{~S}$ rich layers in Bundera Sinkhole (e.g. 1995, 1997, 2002, 2005; Humphreys 1999, W. F. Humphreys unpubl. data) and other anchialine systems (Yager et al. 1994). Lateral transport of oxygenated oceanic water driven by tidal oscillations (10\% of the oceanic tidal range in Bundera Sinkhole; Humphreys et al. 1999) is a possible explanation for this phenomenon and is consistent with our observations of a secondary peak in $\mathrm{O}_{2}$ occurring

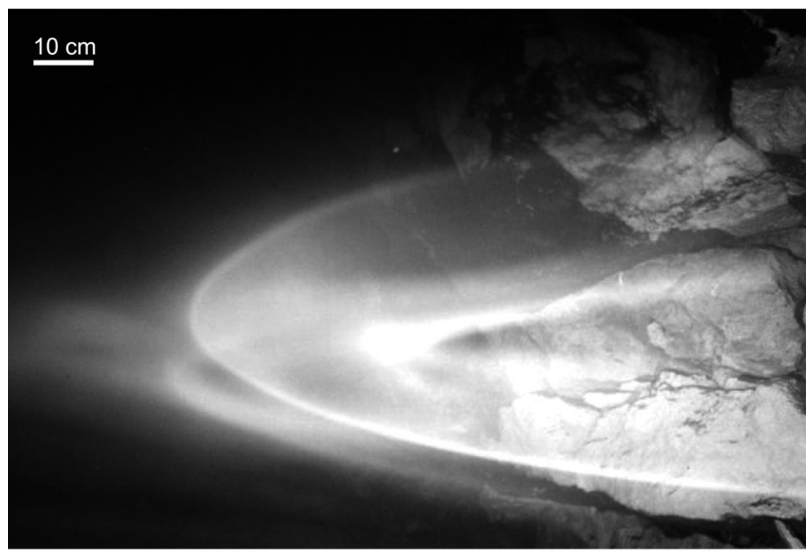

Fig. 7. Cloud of white sulphur-oxidising bacteria observed by divers within Bundera Sinkhole. Depth between 12 and $15 \mathrm{~m}$ 
just below the interface of the marine layer of the water column.

Previously, a polymodal $\mathrm{H}_{2} \mathrm{~S}$ profile was reported in Bundera Sinkhole, with at least 2 conspicuous $\mathrm{H}_{2} \mathrm{~S}$ layers observed, most notably at depths of $5 \mathrm{~m}$ and $16 \mathrm{~m}$ (Humphreys 1999). However, during the time of sampling only a single $\mathrm{H}_{2} \mathrm{~S}$ layer was observed here. Concentrations within this prominent $\mathrm{H}_{2} \mathrm{~S}$ layer were, nonetheless, over an order of magnitude higher than in previous measurements (Humphreys 1999). Concentrations of DIN were also markedly higher here than in previous observations. $\mathrm{NH}_{4}$ exhibited a strong concentration peak at $5 \mathrm{~m}$, loosely correlating to the $\mathrm{H}_{2} \mathrm{~S}$ layer. Correspondence of $\mathrm{H}_{2} \mathrm{~S}$ and $\mathrm{NH}_{4}$ profiles have previously been observed in Bundera Sinkhole (Humphreys 1999), and while it has not been reported in other anchialine systems, this coupling is often observed within meromictic lake systems (e.g. Donachie et al. 1999). As also previously observed at this site, the distributions of $\mathrm{NH}_{4}$ and $\mathrm{NO}_{3}$ exhibited inversely related profiles, which is indicative of nitrification (Ward 1986). These complex patterns in the chemical profile of the Bundera Sinkhole indicate the prevalence of chemoautotrophy and the small-scale partitioning of biogeochemical processes throughout the bulk of the water column.

\section{Phytoplankton distributions and dynamics}

Both the small-scale fluorescence measurements and phytoplankton cell counts indicate that photosynthetic activity was largely restricted to within 3 to $4 \mathrm{~m}$ of the surface of Bundera Sinkhole. FCM cell counts and microscale fluorescence measurements provided broadly comparable depth profiles in the upper $8 \mathrm{~m}$ of the Bundera Sinkhole, suggesting that the populations identified using FCM, to some extent, contributed to the fluorescence observations made with FluoroMAP. A strong peak in both chlorophyll fluorescence and cell counts, occurring at a depth of approximately $1 \mathrm{~m}$, was the dominant feature of all profiles, with fluorescence levels and cell counts both decreasing to low levels below a depth of 4 to $5 \mathrm{~m}$. This thin (10 to $20 \mathrm{~cm}$ ) layer of increased fluorescence intensity was found to strongly wax and wane during a $24 \mathrm{~h}$ light cycle, indicating that it was a dynamic microscale feature of the planktonic environment, rather than a passive accumulation of biomass. The layer was also apparent in all profiles, at a similar position in the water column, confirming that it was not a transient or ephemeral patch of phytoplankton.

Thin layers of phytoplankton have previously been observed in variety of poorly mixed limnetic and marine environments and may occur in response to a number of abiotic and biotic cues (Gasol et al. 1992,
Cowles et al. 1993, McManus et al. 2003). Often thin layers are observed in association with density discontinuities in the transitional zone between differing physical features of the water column (Dekshenieks et al. 2001). However, the thin layer of phytoplankton observed here occurred well above the thermo-halocline present in Bundera Sinkhole. Different taxa of phytoplankton can form thin layers, either by swimming or regulating buoyancy to maintain their position within a microenvironment replete in favourable growth conditions (Lindholm 1992). According to Klausmeier \& Litchman (2001), thin layers of phytoplankton occur as a behavioural response to competition for optimum light and nutrient conditions. The location in the water column of the thin layer observed here is consistent with this prediction. The highly turbid conditions in Bundera Sinkhole at the time of sampling restricted significant light penetration to the upper few metres of the water column. Moreover, the fluorescence peak occurred within a layer of highly elevated $\mathrm{NH}_{4}$ concentrations, which in accompaniment with favourable light conditions provided a microenvironment for optimum phytoplankton growth. Diel changes in light intensity may explain the strong shifts in intensity of the chlorophyll layer observed during a $24 \mathrm{~h}$ sampling period.

Alternatively, the chemical nature of the sinkhole, including gradients in $\mathrm{O}_{2}$ and $\mathrm{H}_{2} \mathrm{~S}$, may have contributed to the formation and dynamics of the smallscale peak in phytoplankton biomass observed here. In another karstic lake system, characterised by physicochemical characteristics very similar to the upper $5 \mathrm{~m}$ of Bundera Sinkhole, Gasol et al. $(1992,1993)$ observed a $<10 \mathrm{~cm}$ thick layer of Cryptomonas phaseolus that exhibited several characteristics that parallel the thin layer of fluorescence observed here. They observed a very thin layer of $C$. phaseolus at a depth of approximately $1 \mathrm{~m}$, corresponding to the $\mathrm{O}_{2}-\mathrm{H}_{2} \mathrm{~S}$ interface. This is consistent with the location of the thin layer observed here, which also peaked within the $\mathrm{O}_{2}-\mathrm{H}_{2} \mathrm{~S}$ interface. Very high $\mathrm{H}_{2} \mathrm{~S}$ concentrations inhibit aerobic photosynthesis and may restrict migration further into $\mathrm{H}_{2} \mathrm{~S}$ layers (Gasol et al. 1992, 1993), and this, rather than decreasing light conditions, could explain the location of the thin layer of chlorophyll observed here. Furthermore, the ability to tolerate moderate levels of $\mathrm{H}_{2} \mathrm{~S}$ may provide a refuge from predators that cannot penetrate the boundaries of $\mathrm{H}_{2} \mathrm{~S}$ layers, which may facilitate the formation of strong biomass accumulations within restricted biochemical zones. Cryptomonas has been demonstrated to produce concentration peaks in several karstic lakes and sinkholes (Ichimura et al. 1968, Gasol et al. 1992, 1993), and due to clearly apparent behavioural similarities, it is possible that this organism, or a similar ecotype, is responsible for the thin 
layer observed here. Using a combination of fine resolution fluorometry and FCM, we have been able to show that the stratified physico-chemical profile within Bundera Sinkhole influences the spatiotemporal dynamics of the phytoplankton community, leading to the occurrence of microscale concentration peaks and the limitation of photosynthetic biomass to a particularly narrow window of the water column.

\section{Microbial community structure and stratification}

Meromictic systems are generally characterised by at least 2 distinct microbial communities, corresponding to an upper, mainly aerobic population, and a lower anaerobic population, with increased diversity and biomass accumulations often occurring at the chemocline (Roberts et al. 2000). We indeed observed a strong biomass accumulation at the thermohalocline, but our observations indicate that the complex physico-chemical profile of Bundera Sinkhole supports several stable microniches, sometimes only a few centimetres thick, which create a markedly stratified microbial community. We consistently observed 6 clear bacterial sub-populations, corresponding to at least 3 distinct ecotypes within the Bundera Sinkhole. However, throughout all samples collected in this study, up to 11 sub-populations of bacteria could be discriminated using FCM, but many of these were present in only 1 or 2 discrete samples and were subsequently not included in microbial depth profiles. However, this indicates that the complexity revealed in the depth profiles presented here is an underestimate of the true heterogeneity within Bundera Sinkhole.

The upper metre of the water column was dominated by a bacterial population exhibiting the typical FCM characteristics of a marine or freshwater population of aerobic heterotrophs. This group exhibited the ubiquitous HDNA and LDNA sub-populations that have been widely observed across a broad range of aquatic habitats (Gasol \& del Giorgio 2000). Despite vigorous debate, there is as yet no clear consensus on the identity or ecological relevance of these 2 subgroups. Widespread field and laboratory evidence is suggestive of a metabolic divergence between the 2 groups, with the HDNA population representing more active cells and the LDNA population perhaps corresponding to less active or dormant cells (Gasol et al. 1999, Lebaron et al. 2001). Recent evidence also suggests a significant degree of phylogenetic dissimilarity between the groups (Mary et al. 2006). In Bundera Sinkhole, the HDNA and LDNA groups both exhibited a decreasing trend over the top 1 to $2 \mathrm{~m}$ of the water column, but the relative proportion of HDNA cells decreased from $65 \%$ at the surface to $49 \%$ at $3 \mathrm{~m}$ depth. This trend of decreasing total abundance and percentage of HDNA bacteria paralleled decreasing oxygen levels and increasing $\mathrm{H}_{2} \mathrm{~S}$ concentrations in the surface water, an observation that is consistent with patterns previously observed in the sediment-water interface of a temperate estuary (Seymour et al. 2007). Below a depth of $5 \mathrm{~m}$, the HDNA and LDNA groups were no longer detectable. $\mathrm{H}_{2} \mathrm{~S}$ is highly toxic to most aerobic organisms (Fenchel \& Finlay 1995), so it is probable that the disappearance of these bacterial populations was caused by the very high concentrations of $\mathrm{H}_{2} \mathrm{~S}$ and decreases in $\mathrm{O}_{2}$ occurring between 1 and $6 \mathrm{~m}$ depth.

Opposing the decreases in abundance of the HDNA and LDNA bacterial populations was a significant increase in the abundance of the S1 and S2 bacterial sub-populations. At a depth of $60 \mathrm{~cm}$, these populations exhibited a strong thin (10 to $15 \mathrm{~cm}$ ) layer of elevated abundance, with concentrations increasing by more than 30-fold over a distance of $20 \mathrm{~cm}$. This layer was approximately situated within the boundary of the upper $\mathrm{H}_{2} \mathrm{~S}$ gradient. Chemolithotrophic sulphuroxidising bacteria exhibit sensitive chemotaxis towards desired gradients of $\mathrm{O}_{2}$ and $\mathrm{H}_{2} \mathrm{~S}$, where they form narrow layers (Fenchel 1994). Qualitative evidence for both white chemolithotrophic sulphur-oxidising bacteria and purple photolithotrophic sulphur bacteria occurrence in the water column of Bundera Sinkhole has been reported previously (Humphreys 1999). However, because the first peak in the abundance of the S1 and S2 groups occurred within oxic near-surface waters, we propose that these bacteria are more likely to be white sulphur-oxidising bacteria than photolithotrophic purple or green sulphur bacteria, which are typically restricted to the anoxic zone below the chemocline (Reskóné \& Borsodi 2003). Furthermore, water samples collected from milky plumes observed in isolated patches on the water surface around the edges of the sinkhole, and indicative of white sulphur-oxidising bacteria (Fenchel 1994), exhibited elevated concentrations of S1 and S2 bacteria. Evidence for high levels of sulphur oxidisation within layers of coexisting $\mathrm{O}_{2}$ and $\mathrm{H}_{2} \mathrm{~S}$ has been observed within the chemocline of lakes (Takano et al. 1997), and within subterranean aquatic ecosystems, sulphuroxidising bacteria constitute an important biogeochemical and ecological element (Sarbu et al. 1996, Macalady et al. 2006). The occurrence of these bacteria near to the surface of the water column at Bundera Sinkhole during the time of sampling was almost certainly facilitated by the very high surface concentrations of $\mathrm{H}_{2} \mathrm{~S}$. Migration from the nearby sediments around the edges of the sinkhole into the water column is the most likely source of these bacteria. A second intense layer of S1 and S2 bacteria occurred at $7 \mathrm{~m}$, 
which simultaneously corresponded to equivalent concentrations of $\mathrm{H}_{2} \mathrm{~S}(\sim 60 \mu \mathrm{M})$ and $\mathrm{O}_{2}\left(\sim 0.8 \mathrm{mg} \mathrm{l}^{-1}\right)$ to those observed in the upper peak of these populations, and the approximate position of the thermo-halocline, where biomass accumulations typically occur. Small peaks in the numbers of these bacteria, as well as white veils, were also observed in water samples and by divers, respectively, at 15 to $18 \mathrm{~m}$.

The third group of bacteria identified here consisted of the D1 and D2 sub-populations, which were only found in significant numbers in 4 clear peaks throughout the water column. These abundance maxima, occurring at 1, 7, 13 and $25 \mathrm{~m}$, tended to broadly dissect peaks in $\mathrm{NH}_{4}$ and $\mathrm{NO}_{3}$, suggesting that these populations may be nitrifying bacteria (Hall 1986, Ward 1986). Planktonic chemolithotrophic nitrifying bacteria can occur within the hypolimnion of lakes (Hall 1982), and high rates of nitrification have been observed in other anchialine sinkholes using stable isotope analysis (Pohlman et al. 1997). Furthermore, while in some cases it can occur under very low $\mathrm{O}_{2}$ levels (Philips et al. 2002), nitrification is also a strictly aerobic process (Painter 1970, Ward 1986), so the apparent coupling between peaks in the D1 and D2 populations with the edges of secondary peaks in $\mathrm{O}_{2}$ observed in the deeper regions of Bundera Sinkhole supports the hypothesis that these groups are nitrifying, rather than denitrifying, bacteria. The generally low concentrations of these populations in the upper $6 \mathrm{~m}$ of the water column could be due to competition for $\mathrm{NH}_{4}$ with phytoplankton and heterotrophic bacteria, or inhibition of nitrification by $\mathrm{H}_{2} \mathrm{~S}$ (Joye \& Hollibaugh 1995).

Previously, multiple sub-populations of bacteria have been identified in lake communities using FCM (Button et al. 1996, Andreatta et al. 2004), and smallscale shifts in the relative abundance of bacterial subpopulations have been shown to occur within depth profiles (Andreatta et al. 2004). However, to our knowledge this is the first study to discriminate different functional groups of bacteria according to basic FCM parameters. The use of FCM in this system allowed us to discriminate populations of heterotrophic aerobic bacteria (HDNA and LDNA), as well as putative populations of chemoautotrophic sulphur-oxidising bacteria (S1 and S2) and nitrifying bacteria (D1 and D2). It is notable that, like the aerobic heterotrophic bacterial population, the other bacterial groups could each be divided into 2 discrete sub-populations according to differences in SYBR Green fluorescence.

Bundera Sinkhole appears to represent a complex microbial system, which is partitioned into several niches, separated by spatial scales of centimetres to metres. The upper layer of the water column is dominated by aerobic heterotrophic bacteria, below which populations of chemoautotrophic sulphur-oxidising bacteria and nitrifying bacteria occur. Each population exists within relatively narrow boundaries determined by the physico-chemical profile of the sinkhole. Therefore, as previously indicated (Humphreys 1999), this system is in many ways analogous to other specific habitats, including microbial mats and aquatic sediments, where similar types of stratification occur, although across millimetre rather than centimetre to metre scales (Fenchel \& Riedl 1970).

\section{Stratification of the virus community}

Viruses constitute abundant and important populations within other limnetic systems (Bettarel et al. 2003, Brum et al. 2005), but to our knowledge this is the first study to investigate virus distribution patterns within an anchialine habitat. In this study, viruses were distributed non-uniformly throughout the water column, with the relative abundance and composition of the virus community exhibiting marked variability that often tracked changes in the microbial community. Peaks in virus concentrations occurred at a depth of $7 \mathrm{~m}$, which approximately corresponds to the position of the thermo-halocline in Bundera Sinkhole. This is consistent with previous observations of virus accumulations at physical transition zones, including thermoclines and oxyclines, within stratified water columns (Taylor et al. 2003).

Shifts in virus community composition and characteristics throughout depth profiles have also previously been demonstrated in lakes (Jiang et al. 2004). The patterns observed in this study are in accordance with these trends, with the 4 virus populations exhibiting clearly dissimilar spatial patterns. The V1 and V2 populations resemble the 2 co-occurring virus sub-populations previously discriminated with FCM by a number of workers in a variety of aquatic habitats (Marie et al. 1999, Larsen et al. 2004). The concentrations of these groups have elsewhere been tied to the concentrations of heterotrophic bacteria (Seymour et al. 2005, 2006), and we observed similar correlations here. Concentrations of the V1 and V2 populations declined by up to 6 -fold over the top metre of the water column, mirroring decreases in the abundance of the HDNA and LDNA bacterial populations. This close coupling implies that these 2 groups of viruses represent phages of the HDNA and/or LDNA bacteria observed in the surface waters of Bundera Sinkhole. This clear shift in concentration over such small spatial scales also supports predictions and recent evidence that virus dynamics can be controlled by microscale shifts in microbial abundance (Seymour et al. 2005, 2006). The distribution of the V3 population also exhibited marked microscale spatial heterogeneity, with a 7 -fold 
change in concentration occurring over $15 \mathrm{~cm}$, which was apparently associated with a layer of high concentrations of the S1 and S2 bacterial sub-populations. A positive correlation between the V3 group and S1 and S2 bacterial populations was observed at both centimetre and metre scales, indicating that this group may represent a phage of these bacteria. No clear correlation was observed between the V4 population and any identified microbial population. However, significant numbers of this virus group were only observed in the thermo-halocline, where increased microbial diversity is likely to persist, and it is possible that the host community for this population of viruses may have been restricted to this zone. The FCM analysis applied here has allowed us to provide putative links between discrete virus populations and bacterial ecotypes and show clear microscale partitioning of the virus community structure within a stratified habitat. Additionally, the complex virus dynamics, and apparent coupling to the microbial community in Bundera Sinkhole, indicates that viruses may be a significant, but until now overlooked, biotic factor within anchialine systems.

\section{Implications and conclusions}

Anchialine habitats are becoming increasingly recognised as important reservoirs of species richness (Yager 1994, Yager \& Humphreys 1996, Danielopol et al. 2000), but the microbial ecology of these systems has been largely overlooked. Within Bundera Sinkhole, photosynthetic primary production is apparently limited to within the top $15 \%$ of the water column, but the sinkhole still supports a rich and diverse community of macro- and microorganisms (Yager \& Hunphreys 1996, Humphreys 1999, Humphreys et al. 1999). Chemoautotrophic organisms such as sulphuroxidising and nitrifying bacteria can contribute up to $100 \%$ of primary production (Sarbu et al. 1996) and represent the trophic base (Lavrentyev et al. 1997) of subterranean habitats. Our findings indicate that specific microbial populations, including chemoautotrophic groups, can be highly stratified within the water column of anchialine sinkholes, with some populations only present within restricted zones delineated by local water chemistry. The patterns observed here adhere to the growing perception that rather than occupying a homogenous soup, planktonic microbial populations often inhabit microscale niches, leading to marked variability in abundance, activity and composition across very small spatiotemporal scales (Azam 1998, Seymour et al. 2004). Especially within physically stable habitats, such as anchialine sinkholes, this heterogeneity should be considered when interpreting the ecology and biogeochemistry of a system.
Acknowledgements. The skills of the cave divers P. Hosie, P. Boler and K. Smith are greatly appreciated. We also thank S. Bailey for technical support with flow cytometry. This research was funded by the Australian Research Council, the Flinders University School of Biological Sciences and the Australian Department of Defence through the Western Australian Museum Foundation.

\section{LITERATURE CITED}

Alcocer J, Luyo A, Sanchez MR, Escobar E, Sanchez M (1999) Bacterioplankton from cenotes and anchialine caves of Quintana Roo, Yucatan Peninsula, Mexico. Rev Biol Trop 47:73-80

Andreatta S, Wallinger MM, Piera J, Catalan J, Psenner R, Hofer JS, Sommaruga R (2004) Tools for discrimination and analysis of lake bacterioplankton subgroups measured by flow cytometry in a high-resolution depth profile. Aquat Microb Ecol 36:107-115

Azam F (1998) Microbial control of oceanic carbon flux: The plot thickens. Science 280:694-696

Bettarel Y, Amblard C, Sime-Ngando T, Carrias JF, Sargos D, Garabetian F, Lavandier P (2003) Viral lysis, flagellate grazing potential and bacterial production in Lake Pavin. Microb Ecol 45:119-127

Bishop RE, Kakuk B, Torres JJ (2004) Life in the hypoxic and anoxic zones: metabolism and proximate composition of Caribbean troglobitic crustaceans with observations on the water chemistry of two anchialine caves. J Crustac Biol 24:379-392

Brum JR, Steward GF, Jiang SC, Jellison R (2005) Spatial and temporal variability of prokaryotes, viruses, and viral infections of prokaryotes in an alkaline, hypersaline lake. Aquat Microb Ecol 41:247-260

Brussaard CPD (2004) Optimization of procedures for counting viruses by flow cytometry. Appl Environ Microbiol 70: 1056-1513

Button DK, Robertson BR, Jüttner F (1996) Microflora of a subalpine lake: bacterial populations, size, and DNA distributions, and their dependence on phosphate. FEMS Microbiol Ecol 21:87-101

Cowles TJ, Desiderio RA, Neuer WS (1993) In situ characterisation of phytoplankton from vertical profiles of fluorescence spectra. Mar Biol 115:217-222

Danielopol DL, Baltanás A, Humphreys WF (2000) Danielopolina kornickeri sp. n. (Ostracoda: Thaumatocypridoidea) from a western Australian anchialine cavemorphology and evolution. Zool Scr 29:1-16

Dekshenieks MM, Donaghy PL, Sullivan JM, Rines JEB, Osborn TR, Twardowski MS (2001) Temporal and spatial occurrence of thin phytoplankton layers in relation to physical processes. Mar Ecol Prog Ser 223:61-71

Donachie SP, Kinzie RA III, Bidigare RR, Sadler DW, Karl DM (1999) Lake Kauhako, Moloka'i, Hawai'i: biological and chemical aspects of a morpho-ectogenic meromictic lake. Aquat Microb Ecol 19:93-103

Doubell MJ, Seuront L, Seymour JR, Mitchell JG (2006) A high resolution fluorometer for mapping microscale phytoplankton distributions. Appl Environ Microbiol 72: 4475-4478

Fenchel T (1994) Motility and chemosensory behaviour of the sulphur bacterium Thiovulum majus. Microbiology 13: 389-394

Fenchel T, Finlay BJ (1995) Ecology and evolution in anoxic worlds. Oxford University Press, Oxford

Fenchel TM, Riedl RJ (1970) The sulfide system: a new biotic 
community underneath the oxidised layer of marine sand bottoms. Mar Biol 7:255-268

Gasol JM, del Giorgio PA (2000) Using flow cytometry for counting natural planktonic bacteria and understanding the structure of planktonic bacterial communities. Sci Mar 64(2):197-224

Gasol JM, Garcia-Cantizano J, Massana R, Peters F, Guerrero R, Pedrós-Alió C (1991) Diel changes in the microstratification of the metalimnetic community of Lake Cisó. Hydrobiologia 211:227-240

Gasol JM, Guerrero R, Pedrós-Alió C (1992) Spatial and temporal dynamics of a metalimnetic Cryptomonas peak. J Plankton Res 14:1565-1579

Gasol JM, Garcia-Cantizano J, Massana R, Guerrero R, Pedrós-Alió C (1993) Physiological ecology of a metalimnetic Cryptomonas population: relationships to light, sulfide and nutrients. J Plankton Res 15:255-275

Gasol JM, Zweifel UL, Peters F, Fuhrman JA, Hagstrom ^̊ (1999) Significance of size and nucleic acid content heterogeneity as measured by flow cytometry in natural planktonic bacteria. Appl Environ Microbiol 65: 4475-4483

Goddard VJ, Baker AC, Davy JE, Adams DG and others (2005) Temporal distribution of viruses, bacteria and phytoplankton throughout the water column in a freshwater hypereutrophic lake. Aquat Microb Ecol 39: 211-223

Hall GH (1982) Apparent and measured rates of nitrification in the hypolimnion of a mesotrophic lake. Appl Environ Microbiol 43:542-547

Hall GH (1986) Nitrification in lakes. In: Prosser JI (ed) Nitrification. IRL Press, Washington, DC, p 127-156

Humphreys WF (1999) Physico-chemical profile and energy fixation in Bundera Sinkhole, an anchialine remiped habitat in north-western Australia. J R Soc West Aust 82:89-98

Humphreys WF (2001) Milyeringa veritas Whitley 1945 (Eleotridae), a remarkably versatile cave fish from the arid tropics of northwestern Australia. Environ Biol Fishes 62: 297-313

Humphreys WF, Poole A, Eberhard SM, Warren D (1999) Effects of research diving on the physico-chemical profile of Bundera Sinkhole, an anchialine remiped habitat at Cape Range, Western Australia. J R Soc West Aust 82: 99-108

Ichimura S, Nagasawa S, Tanaka T (1968) On the oxygen and chlorophyll maxima found in the metalimnion of a mesotrophic lake. Bot Mag Tokyo 81:1-10

Iliffe TM (2000) Anchialine cave ecology. In: Wilkens H, Culver DC, Humphreys WF (eds) Ecosystems of the world, Vol. 30. Subterranean ecosystems. Elsevier, Amsterdam, p 59-76

Jaume D, Humphreys WF (2001) A new genus of epacteriscid calanoid copepod from an anchialine sinkhole in northwestern Australia. J Crustac Biol 21:157-169

Jiang S, Steward G, Jellison R, Chu W, Choi S (2004) Abundance, distribution and diversity of viruses in alkaline, hypersaline Mono Lake, California. Microb Ecol 47:9-17

Joye SB, Hollibaugh JT (1995) Influence of sulfide inhibition of nitrification on nitrogen regeneration in sediments. Science 270:623-625

Klausmeier CA, Litchman E (2001) Algal games: the vertical distribution of phytoplankton in poorly mixed water columns. Limnol Oceanogr 46:1998-2007

Larsen A, Fonnes Flaten GA, Sandaa RA, Castberg T and others (2004) Spring phytoplankton bloom dynamics in Norwegian coastal waters: microbial community succession and diversity. Limnol Oceanogr 49:180-190
Lavrentyev PJ, Gardner WS, Johnson JR (1997) Cascading trophic effects on aquatic nitrification: experimental evidence and potential implications. Aquat Microb Ecol 13: 161-175

Lebaron P, Servais P, Agogué H, Courties C, Joux F (2001) Does the high nucleic acid content of individual bacterial cells allow us to discriminate between active cells and inactive cells in aquatic systems? Appl Environ Microb 67 (4):1775-1782

Lindholm T (1992) Ecological role of depth maxima of phytoplankton. Ergeb Limnol 35:33-45

Macalady JL, Lyon EH, Koffman B, Albertson LK, Meyer K, Galdenzi S, Mariani S (2006) Dominant microbial populations in limestone-corroding stream biofilms, Frasassi Cave system, Italy. Appl Environ Microbiol 72:5596-5609

Marie D, Partensky F, Jacquet S, Vaulot D (1997) Enumeration and cell cycle analysis of natural populations of marine picoplankton by flow cytometry using a novel nucleic acid dye. Appl Environ Microbiol 63:186-193

Marie D, Brussard CPD, Thyraug R, Bratbak G, Vaulot D (1999) Enumeration of marine viruses in culture and natural samples by flow cytometry. Appl Environ Microbiol 65:45-52

Mary I, Heywood JL, Fuchs BM, Amann R, Tarran GA, Burkill $\mathrm{PH}$, Zubkov MV (2006) SAR11 dominance among metabolically active low nucleic acid bacterioplankton in surface waters along an Atlantic meridional transect. Aquat Microb Ecol 45:107-113

McManus MA, Alldredge AL, Barnard AH, Boss E and others (2003) Characteristics, distribution and persistence of thin layers over a 48 hour period. Mar Ecol Prog Ser 261: $1-19$

Olson RJ, Zettler ER, Anderson OK (1989) Discrimination of eukaryote phytoplankton cell types from light scatter and autofluorescence properties measured using flow cytometry. Cytometry 10:636-643

Painter HA (1970) A review of literature on inorganic nitrogen metabolism in micro-organisms. Water Res 4:393-450

Philips S, Wyffels S, Sprengers R, Verstraete W (2002) Oxygen-limited autotrophic nitrification/denitrification by ammonia oxidizers enables upward motion towards more favourable conditions. Appl Microbiol Biotechnol 59: $557-566$

Pohlman JW, Iliffe TM, Cifuentes LA (1997) A stable isotope study of organic cycling and the ecology of an anchialine cave ecosystem. Mar Ecol Prog Ser 155:17-27

Reskóné MN, Borsodi AK (2003) Long term investigations on the changes of the MPN values of bacteria communities participating in the sulphur cycle in Lake Velencei, Hungary. Hydrobiologia 506-509:715-720

Roberts EC, Laybourn-Parry J, McKnight DM, Novarino G (2000) Stratification and dynamics of microbial loop communities in Lake Fryxell, Antarctica. Freshw Biol 44: 649-661

Sarbu SM, Kane TC, Kinkle BK (1996) A chemoautotrophically based cave ecosystem. Science 272 (5270):1953

Seymour JR, Mitchell JG, Seuront L (2004) Microscale heterogeneity in the activity of coastal bacterioplankton communities. Aquat Microb Ecol 35:1-16

Seymour JR, Patten N, Bourne DG, Mitchell JG (2005) Spatial dynamics of virus-like particles and heterotrophic bacteria within a shallow coral reef system. Mar Ecol Prog Ser 288:1-8

Seymour JR, Seuront L, Doubell M, Waters RL, Mitchell JG (2006) Microscale patchiness of virioplankton. J Mar Biol Assoc UK 86:551-561

Seymour JR, Seuront L, Mitchell JG (2007) Microscale gradi- 
ents of planktonic microbial communities above the sediment surface in a mangrove estuary. Estuar Coast Shelf Sci 73:651-666

Stock JH, Iliffe TM, Williams D (1986) The concept 'anchialine' reconsidered. Stygologia 2:90-92

Takano B, Koshida M, Fujiwara Y, Sugimori K, Takayanagi S (1997) Influence of sulfur-oxidizing bacteria on the budget of sulfate in Yugama crater lake, Kusatsu-Shirane volcano, Japan. Biogeochemistry 38:227-253

Taylor GT, Hein C, Iabichella M (2003) Temporal variations in viral distributions in the anoxic Cariaco basin. Aquat Microb Ecol 30:103-116

Ward BB (1986) Nitrification in marine environments. In: Prosser JI (ed) Nitrification. IRL Press, Washington, DC, p $157-184$

Editorial responsibility: Jed Fuhrman,

Los Angeles, California, USA
Weinbauer MG, Höfle MG (1998) Size-specific mortality of lake bacterioplankton by natural virus communities. Aquat Microb Ecol 15:103-113

Wilson RS, Humphreys WF (2001) Prionospio thalanji sp. nov. (Polychaeta: Spionidae) from an anchialine cave, Cape Range, northwest Western Australia. Rec West Aust Mus Suppl 64:105-113

Yager J (1994) Speleonectes gironensis, new species (Remipedia: Speleonectidae), from anchialine caves in Cuba, with remarks on biogeography and ecology. J Crustac Biol 14:752-762

Yager J, Humphreys WF (1996) Lasionectes exleyi, sp. nov., the first remipede crustacean recorded from Australia and the Indian Ocean, with a key to the world species. Invertebr Taxon 10:171-187

Submitted: January 21, 2007; Accepted: September 27, 2007 Proofs received from author(s): November 28, 2007 